\title{
Predation of Apiomerus pilipes (Fabricius) (Hemiptera, Reduviidae, Harpactorinae, Apiomerini) over Meliponinae bees (Hymenoptera, Apidae), in the State of Amazonas, Brazil
}

\author{
Alexandre Coletto da Silva ${ }^{1} \&$ Hélcio R. Gil-Santana ${ }^{2}$ \\ 1 Grupo de Pesquisas em Abelhas, Coordenação de Pesquisas em Ciências Agronômicas, Instituto Nacional de Pesquisas da \\ Amazônia. Avenida André Araújo 2936, Caixa Postal 478, 69083-000 Manaus, Amazonas, Brasil. \\ E-mail: alexbelha@hotmail.com \\ ${ }^{2}$ Laboratório Nacional e Internacional de Referência em Taxonomia de Triatomíneos, Instituto Oswaldo Cruz. Avenida Brasil \\ 4365, Manguinhos, 21045-900 Rio de Janeiro, Rio de Janeiro, Brasil.
}

\begin{abstract}
The present work shows the occurrence of an intense predatory activity on adults working Meliponinae bees (Hymenoptera, Apidae), by Apiomerus pilipes (Fabricius, 1787) (Hemiptera, Reduviidae, Harpactorinae,Apiomerini) at a meliponary in the Instituto Nacional de Pesquisas da Amazônia (INPA, Manaus), Amazonas State, Brazil. KEY WORDS. Assassin bugs, natural enemies, stingless bees.
\end{abstract}

RESUMO. O presente trabalho registra a ocorrência de intensa atividade predatória de Apiomerus pilipes (Fabricius, 1787) (Hemiptera, Reduviidae, Harpactorini, Apiomerini) sobre operárias adultas de meliponíneos (Hymenoptera, Apidae), no meliponário experimental do Instituto Nacional de Pesquisas da Amazônia (INPA, Manaus), Estado do Amazonas, Brasil. O meliponário se encontra num fragmento de vegetação secundária no próprio INPA. PALAVRAS CHAVE. Abelhas sem ferrão, inimigos naturais, percevejos predadores.

Sting bee keeping has been done since ancient times. Before Christ civilizations, mainly those from the Mediterranean Area, Asia Minor, Egypt, India and China have in some instances been known to establish rustic systems for maintaining a feasible exploitation of species of Apis Linnaeus, 1758 honeybees for well over 5400 years. However, prior to the sugar cane and European bee introduction by the newly arrived European settlers, there were no bees belonging to Apis, both in the American and Australian continents. Instead there was a large variety of species of bees possessing non-functional stings, such as the meliponines - considered to be good honey producing bees and hence were considered to be the main source for sugar at that time (Zozaya Rubio \& Espinosa Montaño 2001, Hogue 1993). The keeping of those bee species got to be known as meliponiculture, a term which was initially proposed by NogueIra-NeTo (1953).

In the past, the pre-Columbus people were the first to domesticate several species of stingless bees, which led to the development of this activity in at least four places in Central and South America (KerR et al. 2001b). These people learned how to develop several useful manners of taking advantage of this product, such as for the production of candles, waterproofing material to be used on ships, and medicines, which are still being used by country folks nowadays (Hogue 1993).

Among the meso-american indigenous cultures, the
Mayans showed to possess a lot of useful and good quality information concerning the development of this subject in the Mexican southern and south-eastern areas, as well as other countries such as, Belize, Guatemala, Honduras, El Salvador, Nicaragua and a part of the southern Costa Rica (ZozAYA Rubio \& Espinosa Montaño 2001). Melipona beecheii Bennet, 1831 were the principal domesticated bee among the Mayan, in the peninsula Yucatan, in Mexico (revision in WeAver \& Weaver 1981), being still used for the meliponiculture in this country. That bee, commonly known as "Xunan kab" and "colecab", which mean "lady bee", was held as a deity symbol in the Mayan religious culture (Kerr et al. 2001b, Zozaya Rubio \& Espinosa Montaño 2001, De Jong 2001). Differently from other species such as Melipona yucatanica Camargo, Moure \& Roubik, 1988, Frieseomellita nigra Cresson, 1878, Trigona fulviventris Guérin, 1835 and many others, Melipona beecheii beecheii Bennet, 1831 is the only one that was domesticated, and for that reason the Mayans believed that it should live together with their people (DE Jong 2001).

In the recent past the Kayapó indians have shown the greatest amount of good quality useful knowledge on meliponiculture among all Brazilian indigenous people (Posey 1981, 1983a,b, Posey \& Camargo 1985, Camargo \& Posey 1990). However, for several reasons their knowledge is not being used by the present generations and thus will not be conveyed to the 
future generations, which can lead to the complete loss of this valuable information by the Kayapó population. Nowadays, stingless bee keeping is still expressive among the country folk population. They are able to obtain several products like brews, seasonings and medicines from this activity (Hogue 1993).

Several institutions and organizations have been doing diligent efforts to develop the meliponicultura in Brazil. In the North area, the Group of Bees Researches (GPA) of the Instituto Nacional de Pesquisas da Amazônia (INPA) through scientific and extension projects have beneficiary at least six different indigenous communities (Ticuna, Cocama, Mura, Saterê Mawé and Mayoruna) and four riverine communities. It is being possible to improve the quality of life of several families in the countryside of the State of Amazonas (KERR et al. 2001a) through the use of classic handling techniques allied to the model of modified rational box designed by Oliveira \& KerR (2000).

The stingless bees are common and conspicuous in the center of the Neotropical area, especially in low lands, with humid forests (Hogue 1993). KeRR (1998) affirms that in Brazil, those bees are responsible for 30 to $90 \%$ of the pollination of the native plants depending on the geographical place considered.

As any type of animal breeding, the meliponiculture also faces problems with natural enemies of the bees that can commit the state of the beehives taking, in some cases, even the destruction of the colony. The man can be considered the largest enemy of the native bees, for the destruction of the forests and consequently of their nests, placing them in extinction risk (KerR et al. 1994, 1999). Another examples of bees' natural enemies constantly mentioned in the literature are: the spiders, flies (Diptera, Phoridae), other species of pillage bees, ants, termites and even some lizards (KerR et al. 1996, Nogueira-Neto 1970, 1997).

This work focuses in behaviour observations of predation of stingless bees for a natural enemy of the group of the apiomerines.

The Apiomerini species are exclusive of the New World, now represented by 11 genera, all with amazon species, while in the Neartic area there are only some species of Apiomerus Hahn, 1831 (Froeschner 1988, Maldonado Capriles 1990, GilSANTANA et al. 2002, 2003).

Apiomerus species are diurnal predators that live on the plants and at least some of them use sticky material (resins) on the anterior tibia to hold prey (SCHuH \& Slater 1995).

All the species of Apiomerini have been revealed polyphagous, attacking plague insects as useful insects (GIL-SANTANA et al. 2003).

Apiomerus is composed now for about 110 species (SCHUH \& SLATER 1995), and most of them were studied in the revision of Costa Lima et al. (1951). In that work, the authors felt emphasis to the aspect of the 7th urotergite of the female, including the presence of foliaceous appendages to that level and the size of it.

On Apiomerus vexillarius Champion, 1899, whose females possess big foliaceous appendages, very similar to Apiomerus pilipes (Fabricius, 1787) (Fig. 2), CHAMPION (1899) wrote that: "The foliaceous appendages of the female of $A$. vexillarius plows bright sanguineous in life, and very conspicuous, looking like two red flags waving about, the insect runs over the surface of fallen timber in search of its prey".

Apiomerus pilipes is distributed by several countries of the Neotropical region (Venezuela, Colombia, French Guyana, Brazil). The adult specimens (Fig. 1) vary among 20 to $27 \mathrm{~mm}$ length, and they have a general patter coloration varying from gray to dark colour, with clearer hemielytra (Costa Lima et al. 1951). The females have well developed hind abdominal foliaceous appendages which, as seen before, they present orange coloration when alive (in vivo) (Fig. 2), that sometimes is maintained in the conserved specimens.

The possible use of Apiomerini species for the biological control of plagues, and its controversies were summarized by Gil-SANTANA (2002) and by Gil-SANTANA et al. (2003).

It was observed that Beharus cylindripes (Fabricius, 1803) (Apiomerini) uses vegetable resins in its front legs for attraction and capture species of Trigona Jurine, 1807 bees, while Manicocoris rufipes (Fabricius, 1787) (Apiomerini) awaits for the arrival of the bees close to the entrance of the beehive, in order to capture them (ADIs 1984).

Nogueira-Neto (1997) reported that in São Paulo and Goiás States, individuals of a relatively ordinary species of Apiomerus wait for the bees, mainly among the flowers, to attack them. However, sometimes they are seen in the meliponaries, killing the bees close to the entrance of the beehives, or near a wild nest (MARQues et al. 2003).

A summary of reports of predation made by Apiomerus species on bees was presented by MARQuEs et al. (2003).

Considering that the scientific works made on the apiomerines are scarce and that the biological data are extremely important for the study of them as agents with potential for use in integrated handling of plagues (AMARAL FilHo et al. 1994, GiL-SANTANA 2002), this article reports the attack of Apiomerus pilipes against Meliponinae bees.

\section{MATERIAL AND METHODS}

The observations were led between September and November 2003. The work took place in an experimental meliponary in the campus of the Instituto Nacional de Pesquisas da Amazônia (INPA), in Manaus, Amazonas State. The place, considered an urban forest fragment, is an extensive green area preserved partially with introduction of some species of ecological, ornamental and economical importance (FERREIRA \& RAMOs 1993).

The vegetation of the campus is characterized as a secondary forest (GENTRY 1978), with the majority part constituted by primary forest species, and the remaining area is constituted by typical species of secondary forest (Prance 1975). The Campus of INPA with 14 ha is separated by an avenue, of an area with 540 ha of forest belonging to the Universidade Federal do Amazonas (UFAM). 

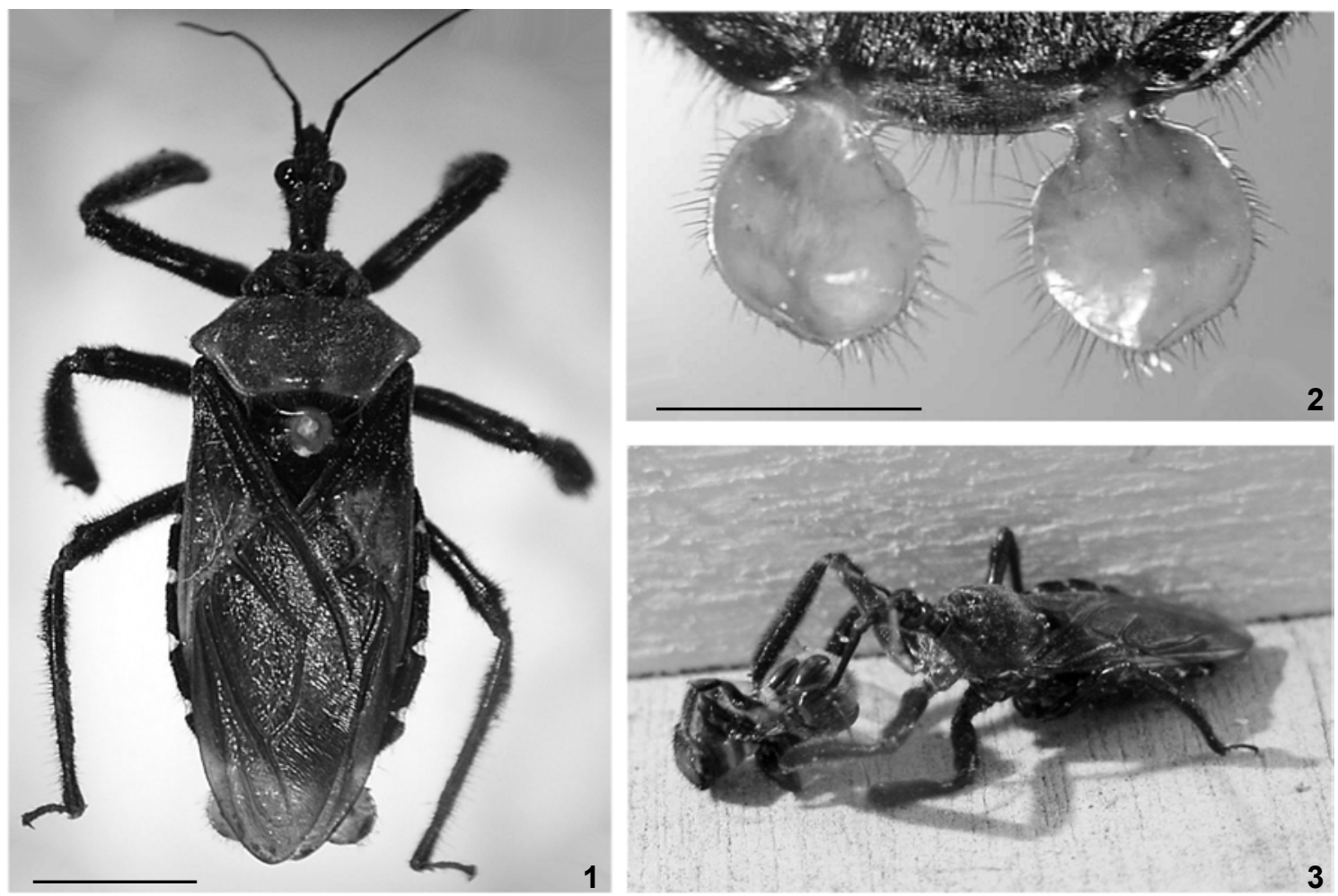

Figures 1-3. Apiomerus pilipes: (1) dorsal view of an adult female; (2) dorsal view of the abdominal foliaceous appendages of an adult female; (3) manipulation of the prey (worker bee of $M$. seminigra merrillae) for $A$. pilipes that introduces the buccal apparel in the base of the antenna of the bee. Scale bars $=5 \mathrm{~mm}$.

The climate of the place is characterized like "Afi" in the Köpen's classification, with rainfall and annual medium temperature of $2458 \mathrm{~mm}$ and $25,6^{\circ} \mathrm{C}$ respectively, with a dry season from June to October (RibeIro 1976). In the data of Instituto Nacional de Meteorologia (INMET) referring to the years from 1961 to 1990 there are records that show the maximum temperature of $31,5^{\circ} \mathrm{C}$ and low temperature of $23,2^{\circ} \mathrm{C}$, average temperature of $26,7^{\circ} \mathrm{C}$, rain precipitation of $2.291,8 \mathrm{~mm}$ and relative humidity of the air of $83 \%$.

The beehives in the meliponary of the INPA campus that were used in this experiment were placed in rational wood boxes and disposed in two systems, individual and collective supports.

The identification of the Apiomerini species was made with the aid of the taxonomic key and respective description, contained in Costa Lima et al. (1951) and by comparison with the data taken from Entomological Collections of Instituto Oswaldo Cruz (IOC) and from the Museu Nacional Universidade Federal do Rio de Janeiro (MNRJ).

In the first behavioural observation, some drops of artificial feeding syrup 50\% (water + sugar) were placed on a piece of alveolus wax of Apis. On the second behavioural observa- tion it was possible to train bees to feed themselves closer the A. pilipes with the aid of the same system (artificial feeding syrup and a piece of alveolus wax).

\section{RESULTS}

Observation 1. A female of $A$. pilipes was observed on a roof covering a stingless beehive. With the aid of the piece of wax containing the syrup it was possible to attract a worker bee of Melipona compressipes manausensis Schwarz, 1932 from another beehive nearby the $A$. pilipes. While the bee fed itself with the syrup the wax piece that supported it was moved closer to the $A$. pilipes. As soon as the bee got near the $A$. pilipes walked toward it and after approximately two seconds it was captured. A. pilipes introduced its rostrum in the membrane between the head and the pronotum, in its dorsal part. Later A. pilipes began to rotate the bee seeking other holes for introduction of its rostrum.

Observation 2. The presence of a female of $A$. pilipes was observed on a rational box of Melipona seminigra merrillae Cockerell, 1919. Initially the female of $A$. pilipes positioned itself opposite to the entrance of the beehive. Three observers were positioned around the box. A. pilipes slowly changed posi- 
tion and came close to the hive entrance. When surrounding the beehive to visualize the entrance, as well as the flow of bees, $A$. pilipes approached slowly and climbed on the mud and vegetable resins (batume) tube present in the entrance of the beehive. A. pilipes waited on this tube for some seconds the opportunity to capture its prey. As there was an intense flow of bees leaving and entering the beehive speedly, A. pilipes was hindered to capture a single bee. Simultaneously, one of the observers trained two worked bees of another species (Melipona rufiventris Lepeletier, 1836), in a beehive inside another box placed a few meters from where this observation took place. The phase of conditioning of the bees finished when they were able to collect the syrup close to where $A$. pilipes was placed in the beehive. In this way, the alveolus wax used in the training was placed near the entrance tube of the beehive and carefully the behaviour observations began. With the first pair of legs positioned upwards $A$. pilipes awaited for the appropriate moment to attack the bee that was feeding itself on the wax. When it captured the prey, $A$. pilipes began a manipulation ritual that seems to be a pattern, which consists of some stages that will be explained later. It is worth to point out that in this observation, as well as in the previous observation, the worker bees that were offered to A. pilipes were previously trained.

Observation 3. An attempt of predation of bees by $A$. pilipes in the entrance door of a beehive was observed. $M$. seminigra merrillae bees were attacked by $A$. pilipes. The bees tried to capture $A$. pilipes and take it to the interior of the beehive through the entrance tube. A great confusion of bees started in the beehive entrance involving at least 20 worker bees. In order to scape, $A$. pilipes killed three bees that tried to defend the colony, taking one of them. In this case there was not training of bees and nor manipulation of $A$. pilipes which were already positioned in the entrance of the beehive.

Observations 4, 5 and 6. Six worker bees of M. compressipes manausensis and six worker bees of M. seminigra merrillae were offered to A. pilipes during three different behavioural experiments. In all the experiments were registered (picture and notebook) the same behavioural patterns of manipulation of the prey that will be described below.

Observation 7 and 8 . Two worker bees of $M$. seminigra merrilae were offered to A. pilipes during two different experiments with the objective of documenting (through filming) the behaviour pattern involved in the predation. In the two experiments were registered the time taken in the immobilization and death of the preys. A. pilipes in the first experiment (observation 7) spent six seconds and 10 second hundredths and in the second experiment (observation 8) another sample of $A$. pilipes spent eight seconds and seven second hundredths to kill the preys.

It is important to emphasize that there is a behaviour pattern verified in all of the eight observations done that can be separated in six behavioural acts: a) the approach of the prey, b) elevation of the first pair of legs, c) the capture of the prey by the dorsal part of its body, d) introduction of the rostrum in the back part of the bee usually between the head and the dorsal part of the body, e) injection of the paralysing toxin, f) manipulation of the prey and introduction of the rostrum in the soft parts of the body as for instance: the junction part between the head and the thorax, the connection part between the thorax and the abdomen, the base of the wings, the spaces between two adjoining tergites and sclerits, genital pore, insertion points of the rostrum, connections between the parts that form the legs and even the antennal alveoli (Fig. 3).

\section{DISCUSSION}

Preliminary data suggest the participation of only females of $A$. pilipes in the predation of the stingless bees. That could be verified because all the species of $A$. pilipes observed possessed the foliaceous appendages in the back part of the abdomen.

There is a behaviour pattern involved in the predation that starts with the capture, death, manipulation and ends with the use of the bee as food source for $A$. pilipes.

Some questions appeared with the present study and they should be the objects of future investigations. For instance, would $A$. pilipes be feeding itself with the hemolynph of the bees or undergoing enzymatic pre-digestion of internal tissues?; What is the biochemical nature of the toxin used by A. pilipes?; Does $A$. pilipes have a general diet or is $A$. pilipes a specialist in the predation of bees?; What is the function of the leaf shaped appendages in the end of the abdomen of $A$. pilipes?; Are the foliaceous appendages of $A$. pilipes related with the pollen collected by the bees, which have, in some cases the same orange coloration?; Does A. pilipes have the behavioural pattern, common to the some apiomerine species, of capturing vegetable resins to use in the first pair of legs as a way to facilitate the predation of bees?

\section{CONCLUSIONS}

With the results obtained through the behavioural observations made in this work, it is concluded that: 1) A. pilipes may be considered as a natural enemy of stingless bees; 2 ) only females of $A$. pilipes were observed predating the Melipona worker bees; 3) A. pilipes shows a behaviour pattern of predation that involves the capture, immobilization, death and manipulation of the prey; 4 ) A. pilipes by using its rostrum is capable to access the hemolynph of the bees seeking for holes in the skeleton; 5) A. pilipes spends a little time (six to eight seconds) to kill your preys; 6) Deeper studies should be led to understand the biochemical nature and the power of action of the toxin used by $A$. pilipes to kill its preys.

\section{REFERENCES}

ADIs, J. 1984. Eco-entomological observations from the Amazon. V. Feeding habits of Neotropical "bee killers" and resin bugs (Apiomerinae: Reduviidae: Hemiptera). Revista de Biolo- 
gia Tropical, San José, 32 (1): 151-153.

Amaral Filho, B.F.; I. Gióia; C.M. Waib; E. Mendeleck \& F.L. Cônsoli. 1994. Observações sobre a biologia de Apiomerus lanipes (Fabricius) (Hemiptera, Reduviidae). Revista Brasileira de Zoologia, Curitiba, 11 (2): 283-288.

Camargo, J.M.F. \& D.A. Posey. 1990. O Conhecimento dos Kayapó Sobre as Abelhas Sociais Sem Ferrão (Meliponinae, Apidae, Hymenoptera). Notas Adicionais Boletim Museu Paraense Emílio Goeldi, Zoologia, Belém, 6 (1): 17-42.

Champion, G.C. 1899 - Insecta Rhynchota. HemipteraHeteroptera, Vol II. p. 229-243. In: F.D. Godman \& O. SALviN (Eds). Biologia Centrali Americana. Rhynchota. London, $\mathrm{XIV}+416 \mathrm{p}$.

Costa Lima, A.M.; C.A.C. Seabra \& C.R. Hathaway. 1951. Estudo dos Apiômeros (Hemiptera: Reduviidae). Memórias do Instituto Oswaldo Cruz, Rio de Janeiro, 49: 273-442.

De Jong, Harriet. 2001. La meliponicultura en la cosmovision Maya, p. 10-18, In: Memorias del II Seminário Mexicano sobre Abejas Sin Aguijon, una visión sobre su biologia y cultivo. Mérida, Universidad Autónoma de Yucatán, Facultad de Medicina Veterinaria y Zootecnia.

Ferreira, C.A.C. \& J. F. Ramos. 1993. Espécies botânicas do Campus do INPA: arbustivas e arbóreas. Manaus, INPA, $17 \mathrm{p}$.

Froeschner, R.C. 1988. Family Reduviidae Latreille, 1807. The assassin bugs, p. 616-651. In: Catalog of the Heteroptera, or true bugs, of Canada and the continental United States. T.J. Henry \& R.C. Froeschner (Eds). Leiden, Editora E.J. Brill, 958p.

Gentry, A.H. 1978. Diversidade e regeneração da capoeira do INPA, com referência especial as Bignoniaceae. Acta Amazônica, Manaus, 8 (1): 67-70.

GIL-SANTANA, H.R. 2002. Predação de Lagria villosa Fabricius, 1783 (Coleoptera: Lagriidae) por Apiomerus nigrilobus Stål, 1872 (Hemiptera: Reduviidae: Apiomerinae) em Cabo Frio, Estado do Rio de Janeiro, Brasil. Entomología y Vectores, Rio de Janeiro, 9 (2): 201-208.

Gil-Santana, H.R.; L.A.A. Costa \& S.O. Zeraik. 2002. Sinonimização de Paramanicocoris Lima, Hathaway \& Seabra, 1948 e Manicocoris Stål, 1866, com redescrição de $M$. rubroniger (Lima, Hathaway \& Seabra, 1948), comb. nov. (Hemiptera, Reduviidae, Harpactorinae, Apiomerini). Boletim do Museu Nacional, Nova Série, Zoologia, Rio de Janeiro, 490: 1-7.

Gil-Santana, H. R.; L.A.A. Costa; D. Forero \& S.O. Zeraik. 2003. Sinopse dos Apiomerini, com chave ilustrada para os gêneros (Hemiptera-Heteroptera, Reduviidae, Harpactorinae). Publicações Avulsas do Museu Nacional, Rio de Janeiro, 97: 1-24.

Hogue, C.L. 1993. Latin American Insects and Entomology. Los Angeles, University of California Press, 536p.

KerR, W.E. 1998. As Abelhas e o Meio Ambiente. Anais do XII Congresso Brasileiro de Apicultura, Salvador, p. 27-30.
Kerr, W.E.; G.A. Carvalho \& V.A. Nascimento. 1994. Há Salvação para os Meliponínios?. Anais do I Encontro Sobre Abelhas, Ribeirão Preto, 1: 60-65.

. 1996. Abelha Uruçu: Biologia, Manejo e Conservação. Belo Horizonte, Ed. Fundação Acangaú, 144p.

- 1999. The probable consequences of the destruction of Brazilian stingless bees, p. 393-403. In: C. РADOCH; J.M. Ayres; M. Pinedo-Vasquez \& A. Henderson (Eds). Várzea: diversity, development and conservation of Amazonia's whitewater flood plains. New York, The New York Botanical Garden Press, Section 6.

Kerr, W.E.; G.A. Carvalho; A. Coletto-Silva \& M.G.P. Assis. 2001a. Aspectos pouco mencionados da biodiversidade amazônica, p. 20-41. In: Ministério da CiênCia e Tecnologia (Ed.). Biodiversidade, Pesquisa e Desenvolvimento na Amazônia. Parcerias Estratégicas. Brasília, vol. 12.

Kerr, W.E., M. Petrere Jr. \& J.A.F. Diniz-Filho. 2001b. Informações biológicas e estimativa do tamanho ideal da colmeia para a abelha tiúba do Maranhão (Melipona compressipes fasciculata Smith - Hymenoptera, Apidae), Revista Brasileira de Zoologia, Curitiba, 18 (1): 45-52.

Maldonado Capriles, J. 1990. Systematic Catalogue of the Reduviidae of the World (Insecta: Heteroptera). Caribbean Journal of Science, Mayagüez, (Special Edition): 1-694.

Marques, O.M.; H.R. Gil-Santana; A.C.A. Magalhães \& A.A.L. Carvalho. 2003. Predação de Apiomerus lanipes (Fabricius, 1803) (Hemiptera: Reduviidae) sobre Apis mellifera (Linnaeus, 1758) (Hymenoptera: Apidae), no Estado da Bahia, Brasil. Entomología y Vectores, Rio de Janeiro, 10 (3): 419-429.

Nogueira-Neto, P. 1953. A criação de abelhas indígenas sem ferrão (Meliponinae). São Paulo, Chácaras e Quintais, 280p. . 1970. A criação de abelhas indígenas sem ferrão (Meliponinae). São Paulo, Chácaras e Quintais, $2^{a}$ ed., 365p. . 1997. Vida e criação de abelhas indígenas sem ferrão. São Paulo, Editora Nogueirapis, 446p.

Oliveira, F. \& W.E. Kerr. 2000. Divisão de uma colônia de jupará (Melipona compressipes) usando-se o método Fernando Oliveira. Manaus, INPA, 7p.

Posey, D.A. 1981. A Apicultura Popular dos Kayapó. Revista Atualidade Indígena, Brasília, 20: 36-41.

- 1983a. Folk apiculture of the Kayapó Indians of Brazil. Biotropica, Lawrence, 15 (2): 154-158.

- 1983b. Keeping of Stingless bee by Kayapó Indians of Brazil. Journal of Ethnobiology, New York, 3 (1): 63-73.

Posey, D.A. \& J.M.F. Camargo. 1985. Additional Notes on the Classification and Knowledge of Stingless Bees (Meliponinae, Apidae, Hymenoptera) by Kayapó Indians of Gorotire, Pará, Brazil. Annals of Carnegie Museum, Pittsburgh, 54 (8): 247-274.

Prance, G.T. 1975. The history of the INPA capoeira based on ecological studies of Lecythidaceae. Acta Amazônica, Manaus, 5 (3): 261-263. 
Ribeiro, M.N.G. 1976. Aspectos climatológicos de Manaus. Acta Amazonica, Manaus, 6 (2): 229-233.

SCHUH, R.T. \& J. A. SLAter. 1995. True bugs of the world (Hemiptera: Heteroptera): classification and natural history. New York, Cornell University Press, 336p.

WEAVER, N. \& E.C. WEAVER. 1981. Beekeeping with the stingless bee Melipona beecheii, by the Yucatean Maya. Bee World,
Cardiff, 62: 7-19.

Zozaya Rubio, J.A. \& L. Gpe. Espinosa Montaño. 2001. Las Abejas Indigenas en Las Antiguas Culturas Mesoamericanas, p. 39, In: Memorias del II Seminário Mexicano sobre Abejas Sin Aguijon, una visión sobre su biologia y cultivo. Mérida, Universidad Autónoma de Yucatán, Facultad de Medicina Veterinaria y Zootecnia.

Received in 26.II.2004; accepted in 20.IX.2004.

Revista Brasileira de Zoologia 21 (4): 769-774, dezembro 2004 